\title{
Depression, Anxiety, and Stress Scales 42 (DASS-42) in Dari-Language: Validity and Reliability Study in Adults, Herat, Afghanistan
}

\section{Dari Dilinde Depresyon, Kaygı ve Stres Ölçeği 42 (DASS-42): Yetişkinlerde Geçerlik ve Güvenirlik Çalışması, Herat, Afganistan}

(i) Nasar Ahmad SHAYAN1', io Aziz-ur-Rahman NIAZI ${ }^{1}$, id Abdul Momen WASEQ ${ }^{2}$, io Hilal ÖZCEBE 3

${ }^{1}$ Herat University Herat Medical Faculty, Department of Public Health, Herat, Afghanistan

${ }^{2}$ Herat University Faculty of Medicine, Department of Internal Medicine, Herat, Afghanistan

${ }^{3}$ Hacettepe University Faculty of Medicine, Department of Public Health, Ankara, Turkey

\section{ABSTRACT}

Objective: This study aimed to assess the validity and reliability of Depression, Anxiety, and Stress Scales-42 (DASS-42) in Dari, in adult population of Herat province of Afghanistan.

Methods: The Dari-translated version of DASS- 42 questionnaire was administered to 1310 non-clinical samples randomly selected in Herat. Internal reliability, exploratory factor analyses, confirmatory factor analyses and Pearson's product moment correlation were assessed to test the validity and reliability of the questionnaire. Data analyses were performed in IBM SPSS Statistics 23.0 and AMOS 23.0.

Results: Internal consistency of the Dari-translated version of DASS-42 questionnaire subscales was high with Cronbach's alpha values of $0.888,0.866$ and 0.833 for depression, anxiety and stress, respectively. Construct validity was further supported with acceptable correlation measures of $0.799,0.822$ and 0.818 for depression, anxiety and stress subscales, respectively, which all were statistically significant $(\mathrm{p}<0.05)$. Confirmatory factor analysis gave acceptable goodness-of-fit indices.

Conclusion: The Dari-translated version of DASS-42 questionnaire is a reliable and valid assessment tool for identification and measurement of the magnitude of depression, anxiety and stress in the Dari-speaking population of Herat province of Afghanistan.

Keywords: Depression, anxiety, stress, DASS-42, Herat, Afghanistan

\section{ÖZ}

Amaç: Bu çalışmanın amacı Depresyon, Kaygı ve Stres Ölçeği-42 (DASS-42) Dari dilinde Afganistan Heart İlinde erişkinler arasında geçerlik ve güvenirliğini değerlendirmektdir.

Yöntemler: Dari diline tercüme edillmiş DASS-42 anketi, Herat'ta yaşayan nüfustan rastgele belirlenen 1.310 kişiye uygulanmıştır. Testin geçerlik ve güvenirlik analizi, iç tutarlılık, açıklayıcı faktör analizi, doğrulayıcı faktör analizi ve Pearson korelasyon analizi ile değerlendirilmiştir. Veri analizi IBM SPSS Statistics 23.0 ve AMOS 23.0 programlarıyla yapılmıştır.

Bulgular: DASS-42 anketi alt ölçeklerinin Dari dili versiyonunun iç tutarlılığı depresyon, anksiyete ve stress için Cronbach alfa değerleri yüksek değerlerde $(0,888,0.866$ ve 0.833$)$ bulunmuştur. Depresyon, anksiyete ve stres alt ölçekleri için yapı geçerliliği, kabul edilebilir korelasyon değerlerinde bulunmuştur $(0,799,0,822$ ve 0,818$)$; tüm değerler istatistiksel olarak anlamlıdır $(\mathrm{p}<0,05)$. Doğrulayıcı faktör analizi kabul edilebilir uyum iyiliği indeksine sahiptir.

Sonuç: DASS-42 anketinin Dari dili versiyonu, Afganistan'ın Herat ilinin Dari konuşan nüfusda depresyon, anksiyete ve stress sıklığının ölçülmesi için güvenilir ve geçerli bir değerlendirme aracıdır.

Anahtar Sözcükler: Depresyon, anksiyete, stres, DASS-42, Herat, Afganistan

Address for Correspondence: Nasar Ahmad SHAYAN, Herat University Herat Medical Faculty, Department of Public Health, Herat, Afghanistan

E-mail: n.a.shayan@gmail.com ORCID ID: orcid.org/0000-0002-8857-7765

Cite this article as: Shayan NA, Niazi AR, Waseq AM, Özcebe H. Depression, Anxiety, and Stress Scales 42 (DASS-42) in Dari-Language: Validity and Reliability Study in Adults, Herat, Afghanistan.

Bezmialem Science 2021;9(3):356-62.

${ }^{\circ}$ Copyright 2021 by the Bezmiâlem Vakıf University

Bezmiâlem Science published by Galenos Publishing House. 


\section{Introduction}

Depression and anxiety are among the most common mental disorders in human community (1). Depression and anxiety have conceptually and theoretically similarities and sometimes overlapping, especially in the young generation (2). Clark and Watson have developed a depression and anxiety model to specify the specific and common variances of these two illnesses (3). Stress is a biologic response to any intrinsic and external stimulus, the stress can cause changes in brain, and different aspects of the nervous system such as different parts of the brain, immune system functions, cardiovascular system, gastrointestinal system, and endocrine system (4). Furthermore, clinicians and researchers need sensitive and specific instruments to assess the extent of depression, anxiety and stress, for which, several tools have been developed previously. Beck anxiety inventory (BAI) and Beck depression inventory (BDI) have been developed to assess the level of anxiety and depression; however, they do not address the "stress" component as body reactions. To address this, Loviband and Loviband developed "depression, anxiety and stress scale (DASS)" to define, understand and measure the magnitude of these three negative emotional states in adults (5). DASS depression scale assesses the mood, motivation and self-esteem, while the DASS anxiety scale focuses on physiological arousal, fear and panic. DASS stress scale assesses the magnitude of tension and irritability. DASS is able to discriminate between the three negative emotional states as a screening test by researchers and clinicians (6). The original DASS is a 42 -item questionnaire in the English language containing 14 questions for each subscale. There is a short version of the 42 -item questionnaire called DASS-21, which contains 7 questions for assessing depression, anxiety and stress each. Both questionnaires evaluate depression, anxiety and stress in the community as well as clinical settings.

DASS-42 and DASS-21 are used in English spoken countries including England, the United States, Canada and Australia (710). The scales have been translated into different languages. Validity and reliability of translated versions have been assessed for many languages and is underway for others (11-23). Studies conducted in different countries using DASS valid and reliable translations illustrated its internal consistency and validity in both clinical and non-clinical samples in different ethnic groups $(12,15,17,20,22)$. Although DASS has been translated in Persian Language and used on high school students, (23) and nonclinical adults of $18-56$ years old, (20) it has not been validated in the Afghan population yet.

The aim of this study is to assess the validity and reliability of the Dari-translated version of the DASS-42 questionnaire in the adult population of Herat province in western Afghanistan. This will serve as a starting point to use DASS for understanding, identifying and measuring the magnitude of depression, anxiety and stress among Afghan people, living in the war-torn country.

\section{Methods}

Persian translation of DASS- 42 was already present on DASS website, it was downloaded, after a written permission, and used in this study. It is worth noting that despite the fact that although Persian translation was present on the website, it was only validated elsewhere, but not in Afghanistan. A cognitive interview was conducted on 27 participants to both understand the language appropriateness of the questionnaire. The purpose of this study was to validate DASS-42 Dari (Persian) questionnaire in the context of Afghanistan, considering differences in culture and environment.

DASS-42 questionnaire measures the magnitude of depression, anxiety and stress. Each of these three subscales consists of 14 questions answered using 0-3 scale, with 0 meaning "it did not apply to me", and 3 meaning "it applied to me very much". Participants were asked to select one of the four response options for each question. Therefore, for each subscale, the possible score ranged between 0 and 42 . Scores considered normal for depression were $0-9$, for anxiety 0-7 and for stress 0-14. Scores above these ranges indicated the degree of the three mental illnesses, ranging mild to severe, as stated elsewhere (5).

\section{Data Collection}

This was a population-based study conducted in Herat province of Afghanistan. A minimum of 30 individuals were considered for each question, with a further 50 individuals added for a better assessment of the validity and reliability of the Dari-translated version of DASS-42 (24).

Therefore, a total of 1,310 participants aged 18 years and over residing in Herat province were included in the study. Before the initiation of the study, informed consent was obtained from each participant. Participants were native Dari speakers without a known psychological problem. Central Statistics Organization of Herat province was contacted to understand the age- and genderspecific characteristics of the population in each of Herat 15 city suburbs. Participants were selected proportionally randomly in Heart.

A group of 15 professional healthcare workers (physcians, nurses and medical university students) was intensively both theoretically and practically trained for one week to conduct DASS-42 questionnaire by research team in Afghanistan. Although the original format of questionnaires was designed to be self-administered, it was slightly modified to conform an interview-based questionnaire, because of the high illiteracy rate in Afghanistan. During data collection the re-test was done on 251 participants, 2-3 weeks after the initial test.

Data collection was carried out between April and November 2017. Data were screened at the end of each week for consistency and accuracy. Any questionnaire with missing data was excluded from the study.

The methodology and conduct of this research was assessed and approved by the Ethics Committee of the Institutional Review Board and the Research and Development Bureau of Herat University (HU-IRB-032017). 


\section{Statistical Analyses}

Cronbach's alpha coefficients were used to evaluate the internal reliability for each of the DASS- 42 subscales. Cronbach's alpha values of 0.70 and over were considered satisfactory, as described elsewhere (25). Exploratory factor analysis was performed using the principal component analysis with oblimin rotation (Kaiser normalization) for the factor structure. The Kaiser-Meyer-Olkin (KMO) statistic and Bartlett's test of sphericity were carried out to check for sampling suitability and factor analysis. Factor loading greater than 0.32 was considered statistically meaningful, as described elsewhere (26). Item analysis was used to eliminate items which did not represent its own subscale. Confirmatory factor analysis was used to determine the goodness-of-fit of the three construct models of DASS after explanatory factor analysis in Herat population. The following parameters were used to evaluate model fit: Chi-square to df ratio (CMIN/df), the root mean square error of approximation (RMSEA), standardized root mean square residual (SRMR), the goodness-of-fit index (GFI), the adjusted goodness-of-fit index (AGFI), the comparative fit index (CFI), the Tucker-Lewis Index (TLI). The following criteria were used to assess model fit as described elsewhere: CMIN/df $<5$; Standardized RMR $<0.05$; RMSEA $<0.08$; GFI $>0.90$; AGFI $>0.90$; CFI $>0.95$ and TLI $>0.95(27,28)$. Pearson's productmoment correlations was used for assessing test-retest reliability. The test-retest reliability value of 0.70 or above was considered satisfactory, as described elsewhere (27). Mann-Whitney U test was used for comparison of two independent groups. Median and interquartile range (IQR) values were given as descriptive statistics for quantitative data. Qualitative data were summarized using frequency and percentages. A p value of less than 0.05 was considered to indicate a statistically significant difference. Statistical analyses were performed using the Statistical Package for the Social Sciences (IBM SPSS Statistics, Version 23.0; Chicago, IL) and AMOS (Version 23.0)

\section{Results}

Of the 1,310 participants in this study, $48.3 \%$ were male, $58.4 \%$ were married and $33.7 \%$ aged 50 years or over. $62.1 \%$ of participants were from Tajik ethnicity and $62.6 \%$ lived in the urban area. $50.0 \%$ of participants were either illiterate or could only read and write. Only $10.4 \%$ were either university students or graduates. $57.2 \%$ of the participants had no income, while $11.3 \%$ earned less than 50 USD per month. Only $6.4 \%$ of participants claimed a monthly income of over 300 USD (Table $1)$.

Item analysis was made for the scale before the factor analysis. First, we determined the items' extreme arithmetic mean and standard deviation. Item $5(0.45 \pm 0.811)$ in depression subscale, item 20 $(0.49 \pm 0.81)$, item $23(0.47 \pm 0.78)$ and item $30(0.49 \pm 0.81)$ in anxiety subscale and item $8(0.64 \pm 0.91)$, item $22(0.6 \pm 0.89)$ and item $39(0.77 \pm 0.89)$ in stress subscale were removed from DASS42. Item 42 was deleted from the depression subscale because its deleted Cronbach's Alpha was bigger than the overall Cronbach's alpha of the subscale (Table 2).
Principal component analysis with oblimin rotation for Exploratory Factor Analyses was performed for the remaining items after item analysis. Item 3 and item 13 were removed from the depression subscale. Because factor loading of item 3 was smaller than 0.30 and item 13 was loaded on the stress subscale. Item 33 and item 9 could not be loaded to any subscale. Furthermore, items 28, 36 and 40 were loaded on depression subscale. Exploratory Factor Analyses with oblimin rotation

Table 1. Characteristics of participants $(n=1310)$ (Herat 2018)

\begin{tabular}{|c|c|c|}
\hline & $\mathrm{n}$ & $\%$ \\
\hline \multicolumn{3}{|l|}{ Age group } \\
\hline $18-29$ & 317 & 24.2 \\
\hline $30-39$ & 288 & 22.0 \\
\hline $40-49$ & 264 & 20.2 \\
\hline $50-59$ & 216 & 16.5 \\
\hline $60-69$ & 156 & 11.9 \\
\hline $70+$ & 69 & 5.3 \\
\hline \multicolumn{3}{|l|}{ Gender } \\
\hline Male & 633 & 48.3 \\
\hline Female & 677 & 51.7 \\
\hline \multicolumn{3}{|l|}{ Nationality } \\
\hline Tajik & 814 & 62.1 \\
\hline Poshton & 276 & 21.1 \\
\hline Other (Ozbik, Hazara) & 220 & 16.8 \\
\hline \multicolumn{3}{|l|}{ Marital status } \\
\hline Married & 765 & 58.4 \\
\hline Single & 441 & 33.7 \\
\hline Widowed/divorce & 104 & 7.9 \\
\hline \multicolumn{3}{|l|}{ Residence } \\
\hline Urban & 820 & 62.6 \\
\hline Rural & 490 & 37.4 \\
\hline \multicolumn{3}{|l|}{ Education status } \\
\hline Illiterate & 469 & 35.8 \\
\hline Literate (can read and write) & 186 & 14.2 \\
\hline Primary school & 105 & 8.0 \\
\hline Secondary school & 115 & 8.8 \\
\hline High school & 299 & 22.8 \\
\hline University & 130 & 9.9 \\
\hline Master/Ph.D & 6 & 0.5 \\
\hline \multicolumn{3}{|l|}{ Economic status (montly) } \\
\hline No income & 749 & 57.2 \\
\hline Less than $50 \$$ & 148 & 11.3 \\
\hline $50-100 \$$ & 174 & 13.3 \\
\hline $100-200 \$$ & 126 & 9.6 \\
\hline $200-300 \$$ & 29 & 2.2 \\
\hline More than $300 \$$ & 84 & 6.4 \\
\hline Total & 1310 & 100.0 \\
\hline
\end{tabular}


was recalculated for the remaining 27 items. The range of factor loadings (after oblimin rotation) was 0.346 to 0.854 . Among depression items, ten loaded on depression factor, ten on stress factor, and only seven on the depression factor. The principal component analysis showed that the three factors together accounted for $49.481 \%$ of the variance, $\mathrm{KMO}=0.963$, (Approx.
Chi-Square: 1501,61), Bartlett's Test of Sphericity $(\mathrm{p}<0.001)$. Results showed that samples in this study were suitable for factor analysis (Table 2).

The internal reliability of the DASS-42 subscales anxiety, depression, stress was assessed using Cronbach's alpha. Alpha was 0.888 for the depression scale, 0.866 for the stress scale, 0.833

Table 2. Results of factor loading, Cronbach's alpha and test-retest for the three dimensions of DASS ( $n=1310)$

Pattern Matrixa

Component

Depression Stress Anxiety

DASS-depression

37 - nothing to be hopeful

34 - worthless

17 - wasn't worth as a person

31 - unable to be enthusiastic

21 - wasn't worthwhile

38 - life was meaningless

24 - couldn't seem enjoyment

16 - lost interest about everything

10 - to look forward to

26 - down hearted \& blue

\section{DASS-stress}

11- getting upset easily

1 - upset

18 - feeling touchy

27 - irritable

14 - getting impatient

29 - hard to calm down

35 - intolerant

12 - using nervous energy

6 - over-react

32 - difficult to tolerate

DASS-anxiety

4 - breathing difficulty

2 - dryness of mouth

7 - feeling of shakiness

15 - feeling of faintness

25 - awareness of heart action

41 - trembling

19 - perspired

0.750

0.738

0.715

0.692

0.685

0.672

0.525

0.523

0.469

0.346

Extraction Method: Principal Component Analysis.

Rotation Method: Oblimin with Kaiser Normalization

Kaiser-Meyer-Olkin Measure of Sampling Adequacy: 0.963 (Approx. chi-square: 15019,610), Bartlett's Test of Sphericity ( $<<0.001$ )

Explained of the variance (\%)

Cronbach's Alpha

38.611

0.888

6.702

4.168

Test-retest

(Spearman's rho correlation coefficient)

0.799*

0.866

0.833

*: $p<0.001$

\subsection{4 \\ 0.750 \\ 0.743 \\ 0.719 \\ 0.617 \\ 0.565 \\ 0.508 \\ 0.507 \\ 0.494 \\ 0.442}

0.760

0.727

0.614

0.600

0.595

0.584

0.454 
for the anxiety subscales. Subscales have good item-internal consistency (Cronbach's alpha values were higher than 0.70). Spearman's correlation coefficient was used to determine the test-retest reliability. The correlation coefficients were obtained between 0.799 and 0.822 . The subscales showed satisfactory testretest reliability due to a higher than 0.70 correlation (Table 2).

In the validation process of Dari-translated version of DASS- 42 questionnaire, in Herat province, 7 questions from depression component, 6 questions from anxiety component and 4 questions from stress component were omitted (Table 3).

Confirmatory factor analysis (CFA) was used to determine the goodness-of-fit of three constructs of DASS, then the factor structure of DASS has been determined by using exploratory factor analysis. Confirmatory factor analysis gave a three-factor structure with acceptable goodness-of-fit indices. Fig 1. shows the confirmatory model (CMIN/df $=.59$, RMSEA $=0.052(90 \%$

Table 3. The items excluded from the scale

\begin{tabular}{|l|l|}
\hline Items & \\
\hline 3 & No positive feeling \\
5 & Not seem to get going \\
13 & Sad \& depression \\
\hline 42 & Difficult to work \\
\hline 9 & Anxious \\
\hline 20 & Scared \\
\hline 23 & Difficult in swallowing \\
28 & Panic \\
\hline 30 & Feared \\
\hline 36 & Terrified \\
\hline 40 & Worried \\
\hline DASS-stress & \\
\hline 8 & Difficult to relax \\
\hline 22 & Hard to wind down \\
\hline 33 & Difficult to tolerate \\
\hline 39 & Agidated \\
\hline
\end{tabular}

$\mathrm{CI}=0.050-0.055), \mathrm{SRMR}=0.0407, \mathrm{GFI}=0.918, \mathrm{AGFI}=0.904$, $\mathrm{TLI}=0.915$ and $\mathrm{CFI}=0.922$ ).

Table 4 shows median and inter quartile range for three scales by gender groups. Three scales of DASS were statistically different for male and female. The scores of female were higher compared to male.

\section{Discussion}

Quality of life is an important outcome to be considered in chronic disorders such as depression, anxiety and stress. Identification and addressing factors that significantly affect the quality of life is essential in improving the standards of life and well-being. DASS -42 is one of the most common validated

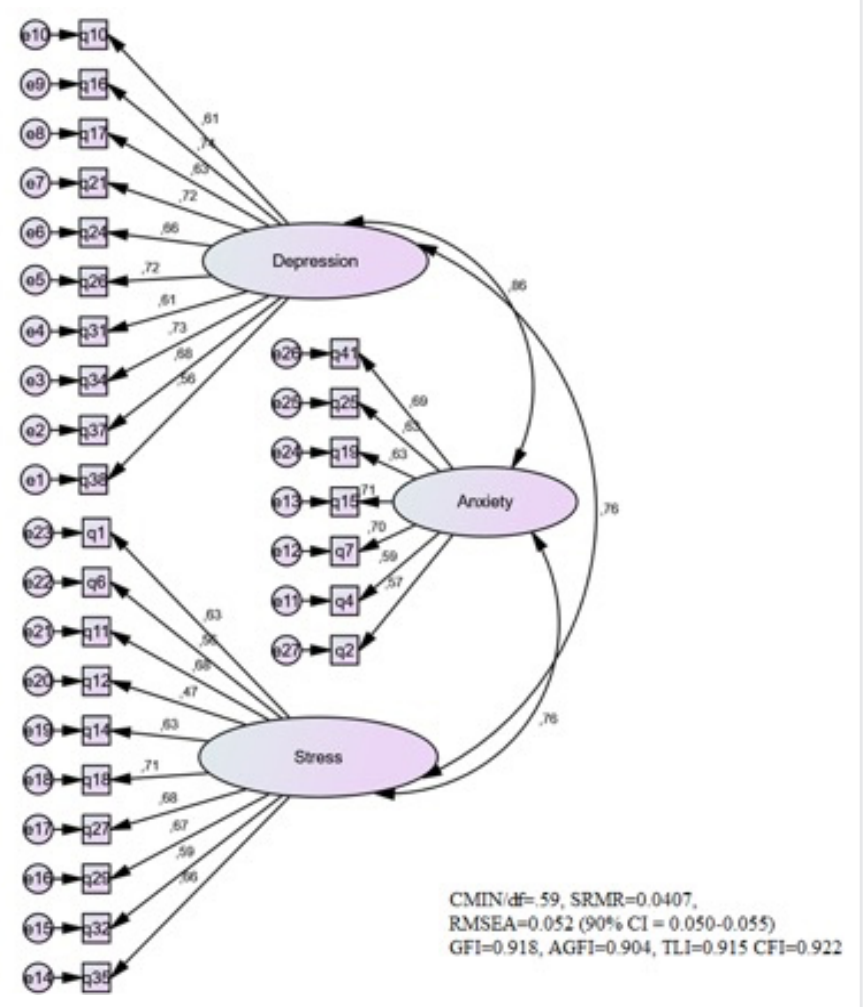

Figure 1. Standardized estimated of the three-dimensions model for DASS obtained from confirmatory factor analysis

Table 4. Comparison of the DASS scores (depression, anxiety, stress) for the Herat population by gender (Herat 2018)

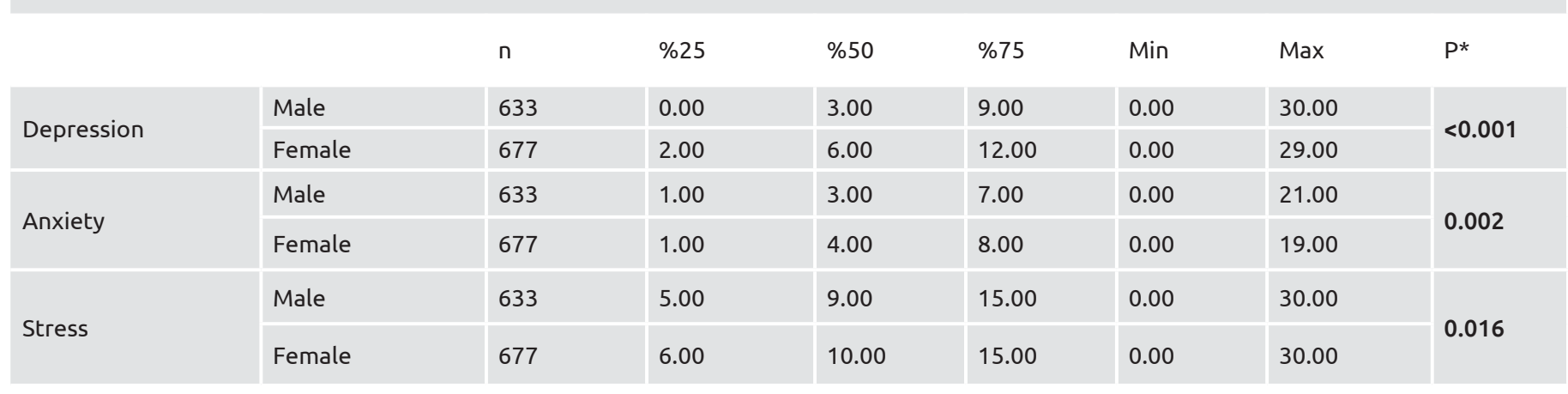


screening test to define depression, anxiety and stress states in many countries (7-23).

We found that the Dari-translated version of DASS-42 questionnaire is a reliable and valid assessment tool for identification and measurement of the magnitude of the three mental illnesses in the adult population living in Herat province of Afghanistan.

Regarding the internal reliability of the DASS-42, the Cronbach's alpha values found in this study were 0.888 for depression, 0.866 for stress and 0.833 for anxiety. The subscales have good iteminternal consistency as the internal consistency (Cronbach's alpha) of each subscale were higher than the referred level as 0.70. Spearman's correlation coefficient was found as 0.799 for depression, 0.822 for stress and 0.818 for anxiety, which were satisfactory. However, our values of Cronbach's alpha were lower than original study conducted by Lovibond and Lovibond (Cronbach's alpha was 0.91 for depression, 0.81 for anxiety and 0.89 for stress) (5). Cronbach's alpha values for university students in Turkey were $0.92,0.86$, and 0.88 for depression, anxiety, and stress, respectively;(13) and for high school students in Turkey were 0.91 for depression, 0.84 for anxiety and 0.86 for stress (12). Internal consistency of DASS-42 subscales was high, with Cronbach's alphas of $0.94,0.88$, and 0.93 for depression, anxiety and stress, respectively. Bayani translated DASS-42 into Persian, and validated in undergraduate students aged between 18 to 51 years; the study reported Cronbach's alpha of 0.92 for depression, 0.88 for anxiety and 0.82 for stress in Iran (21). Furthermore, another study in Iran conducted on university students reported Cronbach's alpha of 0.94 for depression, 0.89 for anxiety and 0.92 for stress (22). In a study conducted in undergraduate and master students in Malaysia, Cronbach's alpha values were 0.88 for depression, 0.85 for anxiety and 0.86 for stress (30). Similarly, Rosnani and Ar reported that Cronbach's alpha values for DASS42 among medical school students, were $0.94,0.90$ and 0.87 for depression, anxiety and stress, respectively (31).

In the validation process of DASS-42 in Dari, 4 questions from depression subscale, 6 questions from anxiety subscale and 4 questions from stress subscale were omitted. Two questions from depression subscale and 7 questions from the anxiety subscale of DASS-42 in Persian validation conducted by Habibi et al. (22) were removed to reach a good exploratory factor analysis. Only 8 items from depression, 4 items from anxiety and 7 items from stress subscales loaded on the original subscales of DASS-42 in the factor analysis of DASS-42 conducted in Malaysia (30). The other Malaysian validation study conducted had also removed 4 items from the original scale to have a good result (31). Asghar also reached to a different scale from the original DASS-42; depression subscale had 18 items, anxiety subscale had 17 items and stress subscale had 7 items in Iran (21). In an attempt to validate DASS-42, Chan et al. (16) removed some items and loaded some items on different subscales of the questionnaire. Bilgel and Bayram (13) also reported that some items were loaded on the different subscales in their study conducted in Turkey. Most of the studies on validation of DASS-42 brought about some changes in the original scales, depending on the differences in cultures and feelings of people for which DASS-42 is translated and validated.

\section{Study Limitations}

This study was conducted on native-Dari speakers who resided in Herat city and is therefore valid for the assessment of magnitude of depression, anxiety and stress in said population. More research is yet to be done to validate this questionnaire in all Dari-speaking Afghan population.

\section{Conclusion}

The Dari-translated version of DASS-42 questionnaire reported here is a valid and reliable tool for the assessment of depression, anxiety and stress state in the Dari-speaking population of Herat province of Afghanistan. This questionnaire can serve as a baseline for a more comprehensive validation analysis of the magnitude of depression, anxiety and stress state in the Darispeaking Afghan population as a whole.

\section{Ethics}

Ethics Committee Approval: Islamic Republic of Afghanistan Ministry of Higher Education Herat University (date: 12.03.2017).

Peer-review: Externally peer reviewed.

\section{Authorship Contributions}

Concept: N.A.S., A.R.N., A.M.W., H.Ö., Design: N.A.S., A.R.N., A.M.W., H.Ö., Data Collection or Processing: N.A.S., A.R.N., A.M.W., H.Ö., Analysis or Interpretation: N.A.S., A.R.N., A.M.W., H.Ö., Literature Search: N.A.S., A.R.N., A.M.W., H.Ö., Writing: N.A.S., A.R.N., A.M.W., H.Ö.

Conflict of Interest: No conflict of interest was declared by the authors.

Financial Disclosure: The authors declared that this study received no financial support.

\section{References}

1. Yusoff MS, Abdul Rahim AF, Baba AA, Ismail SB, Mat Pa MN, Esa AR. Prevalence and associated factors of stress, anxiety and depression among prospective medical students. Asian J Psychiatr 2013;6:12833.

2. Cunha M, Ribeiro A, Andre S. Anxiety, depression and stress in patients with rheumatoid arthritis. Procedia-Social and Behavioral Sciences 2016;217:337-43.

3. Clark LA, Watson D. Tripartite model of anxiety and depression: psychometric evidence and taxonomic implications. J Abnorm Psychol 1991;100:316-36.

4. Yaribeygi H, Panahi Y, Sahraei H, Johnston TP, Sahebkar A. The impact of stress on body function: A review. EXCLI J 2017;16:105772.

5. Lovibond PF, Lovibond SH. The structure of negative emotional states: comparison of the Depression Anxiety Stress Scales (DASS) 
with the Beck Depression and Anxiety Inventories. Behav Res Ther 1995;33:335-43.

6. Osman A, Wong JL, Bagge CL, Freedenthal S, Gutierrez PM, Lozano G. The Depression Anxiety Stress Scales-21 (DASS-21): further examination of dimensions, scale reliability, and correlates. J Clin Psychol 2012;68:1322-38.

7. Henry JD, Crawford JR. The short-form version of the Depression Anxiety Stress Scales (DASS-21): construct validity and normative data in a large non-clinical sample. Br J Clin Psychol 2005;44:22739.

8. Brown TA, Chorpita BF, Korotitsch W, Barlow DH. Psychometric properties of the Depression Anxiety Stress Scales (DASS) in clinical samples. Behav Res Ther 1997;35:79-89.

9. Antony MM, Bieling PJ, Cox BJ, Enns MW, Swinson RP. Psychometric properties of the 42-item and 21-item versions of the Depression Anxiety Stress Scales in clinical groups and a community sample. Psyshol Assess 1998;10:176-81.

10. Ng F, Trauer T, Dodd S, Callaly T, Campbell S, Berk M. The validity of the 21-item version of the Depression Anxiety Stress Scales as a routine clinical outcome measure. Acta Neuropsychiatr 2007;19:30410.

11. Hekimoglu L, Altun ZO, Kaya EZ, Bayram N, Bilgel N. Psychometric properties of the Turkish version of the 42 item Depression Anxiety Stress Scale (DASS-42) in a clinical sample. Int J Psychiatry Med 2012;44:183-98.

12. Akkuş Çutuk Z, Kaya M. The Depression Anxiety and Stress Scale (DASS-42) high school form: The validity and reliability of Turkish version. Electronic Journal of Social Science 2018;17:1327-36.

13. Bilgel N, Bayram N. Turkish version of the Depression Anxiety Stress Scale (DASS-42): Psychometric properties. Archives of Neuropsychiatry 2010;47:118-26.

14. Singh B, Prabhuappa K, Eqbal S, Singh A. Depression Anxiety Stress Scale: Reliability and Validity of Hindu adaptation. International Journal of Education \& Management 2013; 446-9.

15. Webster S, Hawley R, Lopez V. The factor structure of the Thai version of Depression Anxiety and Stress Scale (Thai DASS-42) and its application in a community sample of Thai women living in Sydney, Australia. Journal of Nursing Education and Practice 2013;3:133-41.

16. Chan R, Xu T, Huang J, Wang Y, Zhao Q, Shum D, et al. Extending the utility of the Depression Anxiety Stress Scale by examining its psychometric properties in Chinese settings. Psychiatry Res 2012;200:879-83.
17. Musa R, Fadzil MA, Zain Z. Translation, validation and psychometric properties of Bahasa Malaysia version of the Depression Anxiety and Stress Scales (DASS). ASEAN Journal of Psychiatry 2007;8:82-9.

18. Severino GA, Haynes WD. Development of an Italian version of the Depression Anxiety Stress Scales. Psychol Health Med 2010;15:60721.

19. Bados A, Solanas A, Andres R. Psychometric Properties of the Spanish version of Depression, Anxiety and Stress Scales (DASS). Psicothema 2005;17:679-83.

20. Asghari M, Saed F, Dibajnia P, Zanganeh J. A preliminary study of the validity and reliability of Depression, Anxiety and Stress (DASS) in non-clinical sample. Acad J Behav 2008;15:23-38.

21. Bayani AA. Reliability and preliminary evidence of validity of a Farsi version of the depression anxiety stress scales. Percept Mot Skills 2010;111:107-14.

22. Habibi M, Dehghani M, Pooravari M, Salehi S. Confirmatory factor analysis of Persian version of Depression, Anxiety and Stress (DASS42): Non-clinical sample. Razavi Int J Med 2017;5:e12021.

23. Afzali A, Delavar A, Boriali A, Mirzamani M. Psycometric properties of DASS-42 as assessed in a sample of Kermanshah high school students. J Res Behav Sci 2007;5:81-92.

24. DeVellis RF. Scale Development: Theory and Applications (2nd ed.). New York: SAGE Publications; 2003.

25. Bland JM, Altman DG. Cronbach's alpha. BMJ 1997;314:572.

26. Tabachnick BG, Fidell LS. Using multivariate statistics 5th Ed. Boston: Allyn \& Bacon; 2007.

27. Hopper D, Coughlan J, Mullen M. Structural equation modelling: Guidelines for determining model fit. Electron J Bus Res Methods 2008;6:53-60.

28. Schermelleh-Engel K, Moosbrugger H, Muller H. Evaluating the Fit of Structural Equation Models: Tests of Significance and Descriptive Goodness-of-fit measures. MPR Online 2003;8:23-74.

29. Terwee CB, Bot SD, de Boer MR, van der Windt DA, Knol DL, Dekker J, et al. Quality criteria were proposed for measurement properties of health status questionnaires. J Clin Epidemiol 2007;60:34-42.

30. Imam SS. Depression Anxiety Stress Scales (DASS): Revisited. The 4th International Postgraduate Research Collaquim IPRC Proceeding 2008;184-96.

31. Ramli R, Rosnani S, Ar FA. Psychometric profile of Malaysian ersion of the Depressive, Anxiety and Stress Scale 42-item (DASS-42). MJP Online Early 2012;21:1-7. 